\title{
The Influence of Work Motivation and Work Environment on Employee Performance at Trapo Indonesia
}

\author{
Putri Khairunnisa, Setyo Riyanto \\ Mercu Buana University, Jakarta Indonesia \\ Mercu Buana University, Jakarta Indonesia \\ Email:putrikhairunisa01@gmail.com and setyo.riyanto@mercubuana.ac.id
}

\section{ARTICLE INFO}

Date received : 04 August 2020

Revision date : 16 September 2020

Date received : 09 November 2020

\section{Keywords:}

Work Motivation

Work Environment

Employee Performance

Relationship Work Motivation

\begin{abstract}
The impact of work inspiration and work environment on work execution is very important, and some theoretical and fact assessments in several companies also show work motivation and a supportive environment that provides a very large increase in employee performance, plus in this "NEW NORMAL" period many companies make breakthroughs in running its business once again so that the company can survive in the midst of this crisis. Based on these conditions, the quality of performance and motivation in a company needs to be improved by formulating a new policy in the work system in the company so that it can pass through times like this, which is a new program or procedure in the system to improve employee performance in a company. The method used in this study is the procedure for approaching employees, research that emphasizes the basic principles of work motivation and the environment which seeks to create a new work environment that is more developed in situations like this. The theory outlined below will greatly assist companies, especially Trapo Indonesia, in evaluating and updating inspiration and work environment governance that can have a positive effect on the company and can moreover progress representative execution even better.
\end{abstract}

\section{INTRODUCTION}

At the current time of globalization, every company is required to have great human assets. Great human assets will provide and add to the adequacy, which is also good for the company and can compete with other companies. Companies that need to achieve their goals must inspire and consider the work environment in organizing to provide representatives who work effectively and appropriately. Providing comfort while working for workers through the work environment will determine the level of employee performance. (Sugiyarti, 2012) The work environment is everything that's around a master who can impact himself in carrying out the errands he carries. An environment is said to be good if it happens to be appropriate if the coincidence of the representatives feels comfortable in doing the exercise that is done ideally. So it can be concluded that the work environment is everything that exists around workers when working both physically and nonworking. Physically and directly with implications that can affect workers and their work in the workplace. The expansion to the work environment that affects the inspiration for the implementation of workers also affects the execution of workers. Inspiration is very important for personal achievement. Motivation is a method for influencing or empowering from outside on individuals or work gatherings, so they need to do something that has been determined (Samsudin, 2010) representatives who have excitement are the result of a strong level of inspiration and bad habits instead. Workers who have a strong determination are the result of the need for inspiration. Inspiration is the driving force for someone to contribute as much as possible to the organization's victory to achieve its goals (Siagian, 2014) so that it can be said that motivation is the support that makes someone do the work they need without being hindered so that the work done goes well and results in good execution. Worker execution is very important to be inspected to advance the company's execution. 
The company is not continuously involved in the increase in execution, but for the involvement of the decrease in execution, from the arrival of interviews conducted, there are problems that can reduce execution in the middle of the fasting month. Reducing efficiency due to the impact of the fasting month is due to representatives working while fasting tends to provide lower execution. So it can be concluded that the efficiency of a company is influenced by the implementation of representatives who play an important role in achieving company goals. Based on the portrayal over, researchers are curious about conducting inquire about on "The Influence of Work Motivation and Work Environment on Employee Performance at Trapo Indonesia."

Motivation comes from the Latin word move, which implies thrust or move. Motivation is tended to as it were to human asset administration in common and subordinates in specific. Inspiration questions how quality and potential lead subordinates to work together profitably and effectively accomplish the planning objectives.

Within the conclusion of Veithzal and Rivai (2011. p. 83) states that inspiration can be summed up as takes after:

a. Conditions that individuals move towards a certain objective.

b. Mastery in planning agents and companies in overseeing to work viably, so that the wants of employee and company objectives can be accomplished at the same time.

c. For starters and behavioral bearings, learning to motivate is genuinely behavioral lessons.

d. As vitality to create drive inside.

e. Such conditions influence stirring, coordinating, and keeping up behavior related to the work environment.

According to Sedarmayanti (2012. p. 233), motivation may be an eagerness to spend high-level endeavors towards organizational objectives, which are conditioned by the capacity of endeavors to meet personal needs.

According to the examination conducted by Zameer (2014), motivation plays a basic portion of all open and private organizations.

Motivation is a vital component within the nearness of a man, and capacities to show the triumph of an endeavor or errands looked for after by a man. The motivation of the overwhelming is information and thought of the subordinate's behavior as an encouraging figure within the organization's victory. If the organization can spur or fulfill workers, at that point, representatives will be included and committed to work, which can make way superior organizational efficiency and maintainability successfully (Bunchowong, 2015).

The environment is everything exterior company but has an impact on development and advancement from the company (Surjosuseno, 2015). In common, the environment cannot be controlled by the company, so the company must alter the environment. By paying consideration for the greats work environment or make working conditions that can allow the inspiration to work (Sofyan, 2013. p. 22).

Typically since of the work environment that includes a coordinate impact on workers. The work environment can progress representative execution, and alternately, lacking the working environment will be able to diminish representative execution. A great working environment where workers are said to be conducting an ideal, solid, secure, and comfortable environment. Hence, the assurance and the creation of a great working environment will decide victory in achieving organizational objectives. On the other hand, in case the working environment isn't great to be able to diminish the motivation and resolve, and eventually can debase the execution of workers.

Workers in various firms are encountering work and work-related issues distinguished with the work environment and physical components. Finminiyi (2018) submitted that worker separation is growing, and it has turned out to be imperative to form a working environment that conditions, has seen as a basic calculate for assessing their efficiency (Duru\&Shimawua, 2017).

Unsteady situations outfit laborers with both opportunity and a pile of troubles but through a reasonable working environment, a firm streamlines efficiency and upgrading the organization's goodwill as a working environment, foreseeing a cutting-edge corporate component, which in this way can empower one to pull in skilled representatives. Most companies are starting to reexamine how they are the work environment is controlled and what work environments they offer to staff that has a broad effect on their general execution. An engaging working environment remains the driver or an enabler to improving execution. The work environment is a thought that has a broad effect on their by and large execution. The work environment is a thought that has been operationalized by dismembering the degree to which representatives see their prompt environment 'as their fulfillment characteristic, outward and social needs, and their reasons for remaining with the organization (Iman\&Shhafique, 2014).

Anitha (2014) has empowered the work environment and gather relations and have an imminent impact on the worker's execution. He commented that programs that increment peer association must be progressed to show an amazing work environment for laborers. Kakkos and Trivellas (2011) have found a negative relationship between stretch experienced within the work environment and worker execution. This work environment comprises of physical and non-physical work situations associated with agents that cannot be confined from the advance of exchange within the execution of laborers (Bushiri, 2014). 
Miebi (2014) states that employee performance depends on the eagerness; additionally, the openness of the workers themselves in doing their work. He moreover expressed that by having the readiness and openness of workers to do their employments, it can increment representative efficiency, which moreover leads to performance. Kunze et al. (2013), moreover, clarified that to have a standard execution, supervisors need to get the laborer errand to be done on track to realize the organization's objective or targets. By having work or work done on the track, leaders may be able to screen their laborers and offer them help to develop their execution. Moreover, a reward framework ought to be executed based on employee performance. Typically to spur workers to be able to do more on their assignments. Mmakwe and Ojiabo (2018) characterized performance that depends on inner motivation, but the nearness of inside figures such as essential abilities, intellectual capacity, and resources to do work has an impact. As a result, managers ought to give appropriate working conditions to arrange to create beyond any doubt; the performance of workers meets the required guidelines. This ponder conceives employees' performance to pivot on employees' commitment, efficiency, work effectiveness, and demeanor to work.

Performance is influenced by variables related to work counting part strife push and work / non-work (Jayaweera, 2015). Someone's execution may be a combination of capacity, commerce, and the opportunity it can evaluate from their work (Handayani, 2015). Individual execution is affected by endeavors, capacities, and common circumstances (Riyanto, 2016). Another understanding of execution was communicated by Riyanto et al. (2017) states that execution is the result finished by some person based on the estimation that applies to work in the address. Riyanto et al. (2017) state that execution is the result of certain worker capacities or exercises carried out over a certain period of time. The general performance from an ascending position to a (normal) capacity or training performance number carried out by workers.

According to Mangkunegara (2011. p. 67), the measurements of employee performance are partitioned into five, to be a specific work quality, amount occupations, duties, participation, and activity. Exceptionally fulfilled and upbeat employee higher execution so organization is simple achieves the desired objectives and targets through this higher employee support. Within the field of resources, nearly all executions such as the execution of pros in companies or organizations or companies. For organizations or company specialists, performance is principal to shape each fight to bolster a little performer. But in the case of companies not being able to persuade their specialists to succeed, so it is exceptionally troublesome for companies to be in a competitive exchanging environment (Ahmad, n.d.) An individual's performance is fundamentally favored by inspiration since, in case specialists fulfilled or empowered at that point, they will do work with more imperativeness and where the performance will eventually be incremented (Azar \& Shafighi, 2013).

\section{METODE}

The research method used is descriptive method with a qualitative approach. Through a descriptive method, the researchers thoroughly examined the work inspiration and work environment in the making strides the execution of workers of Trapo Indonesia. The research location of Trapo Indonesia West Jakarta regional head office. Research subjects finance, accounting, and admin divisions. Information collection strategies utilized in this think about are the strategy of perception, interviews, and documentation studies. Information investigation methods in this think about include the steps of data reduction, data display, and drawing conclusions.

\section{RESULTS AND DISCUSSION}

\section{Work Motivation of Employees Trapo Indonesia}

From the results of this study, it was revealed that employee work motivation in any activity that was carried out in achieving its goals requires effort in every component of the organization in a synergic manner. And the efforts made are based on perceptions, attitudes, and realizing personal, group, and ultimately organizational behavior. Achieving optimal goals will provide various benefits, both material and non-material. Therefore, every leader must always try to motivate all components in the organization to achieve organizational goals. The description of the achievement effort, in the context of the organization, is called performance. Work time is about the number of absences done, delays, and the length of work in the year that has been undertaken. Performance is essentially inseparable from the behavior of workers regarding the motivation, ability to think and skills of one's position, and has a relationship with organizational performance. Employee performance is the achievement obtained by someone in carrying out the task. The victory of an organization depends on the execution of the actors of the organization concerned. Therefore, each work unit in an organization must be able to provide work motivation to employees in order to create good performance, because motivation is a process that arouses, directs, and maintains behavior for a certain period of time to achieve goals. Based on the portrayal over it can be concluded that 
motivation is a desire that is contained within every human being or individual that can be influenced from within human beings themselves or comes from a number of outside forces, which can affect the performance results both positively or negatively, depending on the situation and the conditions faced by humans or individuals concerned. In other words, work motivation is one's willingness to direct the will, expertise, and skills at work. Someone who has high motivation will work optimally and optimally as a form of behavior in achieving the goals set. Based on the depiction over it can be concluded that of Trapo Indonesia has tried to provide work motivation to employees by (1) employee-oriented is more important than just work-oriented, (2) holding good supervision and not rigid to employee activities, (3) provide information or communication on the duties or work of employees, and (4) provide incentives to employees within the frame of financial incentives and non-financial incentives.

\section{Employee Performance Of Trapo Indonesia}

From the comes about of the think about, it can be clarified that the workers of Trapo Indonesia always wish that the employees have been able to increase high performance. Because employee performance is the most important thing in achieving organizational goals with high performance from employees allows the success rate of achieving its goals will be higher. Philosophically, the performance contains an outlook on life and a mental state of mind that continuously tries to make strides life. Today's circumstance must be way better than recently. This see of life and demeanor will empower individuals not to feel fulfilled rapidly but will proceed to create themselves and move forward their work skills. Based on the portrayal over it can be concluded that there are several activities and efforts undertaken by Trapo Indonesia in improving employee performance, namely (1) providing the widest possible opportunity for each employee to attend training in accordance with the field of work, (2) division of work for each staff according to the skills of the employees themselves, (3) placing employees inappropriate job positions, (4) rewarding employees who are performing well and giving penalties to employees who are not performing well.

\section{The Relationship Of Work Motivation To The Performance of Trapo Indonesia Employees}

From the results of research at Trapo Indonesia, it was found that the application of work motivation has an impact on progressing worker execution. Because employee performance is the capacity to carry out exercises that create an item or work in understanding with the required quality in a shorter time than the workforce, each organization will essentially have a distinctive arrangement for its human assets to achieve employee performance. In achieving worker execution, there are numerous variables that influence representative execution, counting work inspiration, work teach, job satisfaction, and increased employee stress. The fourth, which affects employee performance, is anticipated to supply a way for representatives to attain better performance since the reason for work inspiration is to supply work eagerness to each worker so that workers can carry out their obligations viably and productively. From the description above, it can be concluded that the work inspiration of Trapo Indonesia, which has a relationship in improving performance, seems to depend very much on the motivation of management elements at all levels of the institutional hierarchy that play a role in it. Therefore what needs to be highlighted in the form of leadership adopted by the relevant institutions. Is the leadership single or group. Leadership motivation at Trapo Indonesia will be adjusted to the criteria to evaluate success in carrying out its leadership functions because motivation and performance are interrelated parts of one another. Increased work motivation will affect employee performance improvement and vice versa. However, what leaders need to remember is that good performance is not possible without being influenced by supporting factors, such as (1) Training, (2) Employee mental and physical abilities, (3) creating harmonious relationships between employees with leaders and fellow employees. Thus, if employees are treated well by superiors or there could be a great relationship between employees, then the worker will take an interest properly within the generation handle so that it'll influence the level of worker performance.

\section{Employee Work Environment Trapo Indonesia \\ In this study, the physical work} environment and non-physical work environment factors are influences on employee performance. Both of these have a contribution to worker 
execution, which is impacted by other components, counting worker inspiration, superiors support for subordinates, the existence of work, and employee relations in the organization. The way to find out the impact of centrality between physical work environment and non-physical work environment factors is a factor that significantly influences employee performance, the results of research conducted by researchers, then the conclusion there's a noteworthy impact between the physical work environment and non-physical work environment is a factor which significantly influences the performance of employees is acceptable. The environment is everything outside the company but has an influence on the advancement and development of the company (Surjosuseno, 2015). In common, the environment cannot be controlled by the company, so the company must alter the environment by paying consideration to the extraordinary work environment or making working conditions that can allow inspiration for work (Sofyan, 2013. p. 22). This will be deciphered that in case the work environment at Trapo Indonesia is getting way better, at that point, the execution of the representatives of Trapo Indonesia will increase. This condition occurs because of the work environment around Trapo Indonesia can influence Trapo Indonesia in carrying out the errands that are charged.

\section{Work Environment Relationship With Employee Performance Trapo Indonesia}

A condition of the work environment is said to be great or fitting in the event that people who are in it can carry out their exercises ideally, sound, secure, and comfortable. The appropriateness of the work environment can have an effect for a long time, and a terrible work environment will make it troublesome to get a compelling and proficient work framework. The comes about of the think about have suggestions for encouraging making strides the consolation of the work environment, the level of work teaches, and representative execution, particularly within the environment at Trapo Indonesia. Attention and renewal of work facilities needed by employees are important for the convenience of employees to be maintained and support employees at work because environmental factors have proven to work well at Trapo Indonesia and can greatly improve employee performance at Trapo Indonesia.

\section{CONCLUSION}

Based on the above theory, ready to derive that motivation and work environment are very influential in company development. Because of these two things we can help and mobilize our employees to be able to make strides their performance with the "method or theoretical basis described above, where work motivation is very fostering the spirit of the development of every employee in the company by providing several things that are the basis of employee needs. , work environment such as providing "training" to improve employee training so employees can alter to the work environment, where the work environment can change at any time, and the working relationship between employees is also very helpful in increasing work motivation so that employee performance is going better and the company continues to grow.

Many things need to be emphasized to improve employee performance starting from several important things such as work relations between employees and superiors to achieve the desired goals, as well as the role of good communication must also be considered and need to be studied further in further research by conducting more case studies detailed and patterned so that it can be a reference material for a company in improving employee performance.

\section{REFERENCES}

Ahmad, M. Wasay. (n.d.). E. \& Malik, S.(2012). Impact of Employee Motivation on Customer Satisfaction: Study of Airline Industry in Pakistan: Interdisciplinary Journal of Contemporary Research in Business, Institute of Interdisciplinary Business Research, 4(6).

Anitha, J. (2014). Determinants of employee engagement and their impact on employee performance. International journal of productivity and performance management.

Azar, M \& Shafighi, A. (2013). The Effect of Work Motivation on Employees' Job Performance: International Journal of Academic Research in Business and Social Sciences, Vol. 3, No. 9 ISSN: 2222-6990.

Bunchoowong, D, (2015), Work Motivation in Public vs Private Sector Case Study of Department of Highway Thailand, Review of Integrative Business and Economics Research, 4(3), 216-221.

Bushiri, C.P. (2014), The Impact of Working Environment on Employees Performance: The Case of Institute of Finance Management in Dar Es Salaam Region. Dissertation of 
Master in Human Resources Management. The Open University of Tanzania.

Duru, C. E. and Shimawua, D. (2017). The effect of work environment on employee productivity: A case study of edo city transport services benin city, edo state Nigeria. European Journal of Business and Innovation Research, 5(5), 23-39

Finminiyi, A.K. (2018). Impact of workplace environmental factors on employee commitment: evidence from north-east Nigeria. International Journal of Scientific Research and Management (IJSRM), 6(7), 575-588

Handayani, R.D. (2015), The influence of work motivation and work environment to the performance of library staff of ten November institute of technology (ITS) Surabaya. Journal of Public Administration and Bureaucracy, 8(5), 35-42.

Imam, A., \&Shafique, M (2014). Impact of employee engagement in retaining employees through mediating effect of job satisfaction and organizational commitment and moderating effect of job stress: A corporate banking sector study of Pakistan. Journal of Applied Environment and Biological. Sciences, 4(12)115

Jayaweera, T. (2015), impact of work environmental factors on job performance, mediating role of work motivation: A study of hotel sector in England. International Journal of Business and Management, 10(3), 56-67

Kakkos, N., \& Trivellas, P. (2011, July). Investigating the link between motivation, work stress and job performance. Evidence from the banking industry. In 8th international conference on enterprise systems, accounting and logistics (pp. 408428).

Kunze, F., Boehm, S., \& Bruch, H. (2013). Organizational performance consequences of age diversity: inspecting the role of diversityfriendly $\mathrm{hr}$ policies and top manager's negative age stereotypes. Journal of Management Studies 50(3), 413-44

Mangkunegara, A. (2011), Human Resource Management Company. Bandung: PT Youth Rosdakarya.
Miebi, U. (2014). Workforce diversity Management and corporate performance of firms in Nigeria. International Journal of Business and Management Review, 2(4), 36-46

Mmakwe, K.A. \&Ojiabo, U. (2018). Work-life balance and employee performance in Nigerian banks, port Harcourt. International Journal of Advanced Academic Research / Social \& Management Sciences, 4(1), 34-47

Riyanto, S. (2016), Selling Yourself: Menang Bersaing Di Era MEA. Jakarta: Kaifa, MarkPlus Inc.

Riyanto, S., Adonia., Ali, H. (2017), Effect of motivation and job satisfaction on the performance of teachers in Mentari School Bintaro (MSB). International Journal: Scholars Bulletin, 3(3), 83-91

Samsudin, S. (2010). Human Resource Management . Bandung: Loyal Reader.

Sedarmayanti. (2012), Human Resources and Work Productivity. Bandung: Bandar Maju.

Siagian, S. (2014). Human Resource Management . Jakarta: PT Raja Grafindo Persada.

Sofyan, D.K. (2013), The effect of work environment on BAPPEDA employee performance. Malikussaleh Industrial Engineering Journal, 2(1), 18-23.

Sugiyarti, G. (2012). Effect Of Work Environment, Culture Organization And Compensation Of Work Satisfaction To Improve Employee Performance (Study On The Economic Faculty Of August 17, 1945 Semarang). UNTAG Scientific Journal Semarang , 105 (3), 129-133.

Surjosuseno, D. (2015), Effect of work environment and work motivation on employee performance in UD production division ADA plastic factory. AGORA, 3(2), 16-27.

Veithzal, R., Sagala, E.Jauvani. (2011), Human Resource Management for the Company. 2nd ed. Jakarta: Raja Grafindo Persada.

Zameer et al.(2014). The Impact of the Motivation on the Employee's Performance in Beverage Industry of Pakistan. International Journal of Academic Research in Accounting, Finance and Management Sciences Vol. 4(1).

\section{Copyright holder:}

Putri Khairunnisa, Setyo Riyanto (2020)

First publication right :

Journal of Social Science

This article is licensed under:

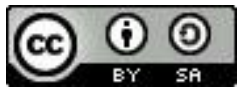

